\title{
PELEVELAN KEMAMPUAN PENALARAN MATEMATIS DENGAN PEMBIASAAN STRATEGI METAKOGNISI SISWA SMP
}

\author{
Kms Muhammad Amin Fauzi
}

Dosen Jurusan Matematika FMIPA Universitas Negeri Medan, Medan

Email :amin_fauzi29@yahoo.co.id

Diterima 2 Juni 2017, disetujui untuk publikasi 29 Juli 2017

\begin{abstract}
Abstrak Penelitian ini bertujuan untuk (1) menganalisis perbedaan peningkatan kemampuan Penalaran matematis siswa antara yang diajar pendekatan metakognisi berbantuan teknik probing dengan teknik prompting; (2) bagaimana pembiasaan strategi metakognisi berpengaruh pada fase-fase pengaturan diri siswa dalam menyelesaikan masalah, khususnya masalah penalaran matematis; dan (3) proses jawaban siswa di tinjau pada level Tacit Use, Aware Use, Strategic Use dan Reflective Use. Penelitian ini merupakan jenis penelitian quasi eksperiment. Instrumen penelitian ini terdiri atas tes kemampuan awal, dan tes kemampuan penalaran matematis siswa berupa lembar proses jawaban siswa untuk dianalisis berdasarkan fase pengaturan diri dan level kogntif dan metakognitif siswa. Teknik analisis data yang digunakan adalah analisis secara deskripstif dan inferensial. Hasil penelitian menunjukkan bahwa: (1) Terdapat perbedaan peningkatan kemampuan penalaran matematis siswa antara yang diajar dengan strategi metakognisi berbantuan teknik probing dan yang diajar dengan pendekatan teknik prompting; (2) Pembiasan strategi metakognisi berpengaruh pada fase pengaturan diri siswa terdiri fase pemikiran awal, fase kontrol kinerja dan fase refleksi diri. Dimana ketiga fase di atas berbeda satu dengan yang lain tetapi saling terkait dan terjadi secara siklus, baik dalam mengajukan dugaan, melakukan manipulasi matematika, menarik kesimpulan dan memberikan alasan atau bukti terhadap kebenaran solusi dan menemukan pola atau sifat dari gejala matematis untuk membuat suatu generalisasi. (3) Level metakognisi siswa dapat digolongkan kedalam tiga level metakognisi dari empat level yang ada. Proses jawaban siswa yang berada ditingkat level rendah dapat tergolong pada tingkat metakognisi Aware Use. Siswa yang berada ditingkat level sedang tergolong pada tingkat metakognisi Strategic Use. Sedang siswa yang berada ditingkat level tinggi tergolong pada tingkat metakognisi Reflective Use.
\end{abstract}

Kata kunci :

Penalaran matematis, strategi metagonis, teknik probing, teknik prompting, level. 


\section{Pendahuluan}

Witherington (Djaali, 2014) mengartikan bahwa "kebiasaan merupakan Kebiasaan dengan sistem terintegrasi ini membentuk kegiatan yang sifatnya berulang-ulang. Makin baik upayanya makin kuat kemauannya dan makin tinggi pula kecendrungannya memperoleh prestasi dalam pendidikan. Sebaliknya makin rendah upaya, makin kurang kemauannya, rendah pulalah kecenderungannya untuk berprestasi.

Kebiasaan belajar dalam penelitian ini merupakan sikap siswa dalam aspek memperhatikan informasi dari guru, kehadiran tepat waktu, mengerjakan tugas pembelajaran, keaktifan bertanya dan menjawab pertanyaan, berpartisipasi aktif dalam kegiatan berdiskusi, mengerjakan pekerjaan rumah, menyediakan waktu belajar di rumah secara khusus, mengulang pelajaran di rumah, menyiapkan berbagai perlengkapan sebelum pembelajaran.

Siswa yang mempunyai kemampuan penalaran matematis yang baik adalah siswa yang mempunyai kemampuan mengajukan dugaan, dapat melakukan manipulasi matematika, dapat menarik kesimpulan, menyusun bukti dengan memberikan alasan atau bukti terhadap kebenaran solusi dan menemukan pola atau sifat dari gejala matematis untuk membuat generalisasi. Dengan kata lain, belajar matematika tidak terlepas dari aktivitas bernalar.

Namun dalam proses pembelajaran matematika di sekolah belum sepenuhnya mengembangkan kemampuan tersebut. Sehingga kemampuan bernalar siswa tidak sesuai dengan jenjang pendidikan yang seharusnya. Rendahnya kemampuan penalaran matematis siswa akan mempengaruhi hasil belajar siswa, yang berdampak pula terhadap rendahnya prestasi belajar siswa di sekolah.

Rendahnya kemampuan penalaran matematika siswa tidak terlepas dari peran guru dalam mengelola pembelajaran. Guru cenderung memindahkan pengetahuan yang dimiliki ke pikiran siswa, mementingkan hasil daripada proses, mengajarkan secara urut halaman per halaman tanpa membahas keterkaitan antara konsepkonsep atau masalah. Siswa diharapkan mampu menirukan perilaku guru terhadap matematika yang diberikannya dan siswa yang dapat "mengkopi" dan menguasai dengan baik bagaimana guru menguraikan bahan matematika (mathematical knowledge), itulah siswa yang dipandang sebagai siswa yang sukses.

Guru tidak hanya memberikan penekanan pada pencapaian tujuan kognitif tetapi juga harus memperhatikan dimensi proses kognitif, khususnya pengetahuan metakognitif dan keterampilan metakognitif. Proses pembelajaran matematika harus dapat melibatkan proses dan aktivitas berpikir siswa secara aktif dengan mengembangkan perilaku metakognitif. Untuk itu diperlukan kreativitas guru dalam penyampaian materi dengan pendekatan metakognisi.

Metakognisi merupakan kesadaran tentang apa yang diketahui dan apa yang tidak diketahui. Sedangkan pendekatan metakognisi merujuk kepada cara untuk meningkatkan kesadaran mengenai proses berpikir dan pembelajaran yang berlaku sehingga bila kesadaran ini terwujud, maka seseorang dapat mengawal pikirannya dengan merancang apa yang diketahui, apa yang ditanya, memantau yang sudah dilaksanakan dan menilai apa yang dipelajarinya (Fauzi dkk, 2016). Proses berpikir biasa terjadi ketika aktivitas belajar berlangsung, sehingga kemampuan metakognisi berkaitan erat dengan aktivitas belajar siswa. Marzano (Peirce, 2003) menyatakan bahwa "If students are aware of how committed (or uncommitted) they are to reaching goals, of how strong (or weak) is their disposition to persist, and of how focused (or wandering) is their attention to a thinking or writing task, they can regulate their commitment, disposition, and attention".

Dari pemaparan di atas maka metakognisi penting untuk dikembangkan pada diri siswa agar mereka memiliki kemampuan penalaran matematis. Karena untuk mendukung proses pembelajaran yang 
meningkatkan kemampuan penalaran matematis siswa diperlukan suatu pengembangan materi pelajaran matematika yang difokuskan pada kesadaran tentang pengetahuan dan proses berpikir siswa. Teknik bertanya baik oleh guru maupun oleh siswa merupakan salah satu teknik yang cocok dalam pembelajaran pendekatan metakognisi.

Suyatno (2009) mengemukakan bahwa: Teknik pembelajaran probing dan prompting adalah pembelajaran dengan cara guru menyajikan serangkaian pertanyaan yang sifatnya menuntun dan menggali, sehingga terjadi proses berpikir yang mengaitkan pengetahuan sikap siswa dan pengalamannya dengan pengetahuan baru yang sedang dipelajari. Pertanyaan-pertanyaan yang dilontarkan pada siswa akan membuat siswa berpikir lebih rasional tentang pengetahuan yang telah diperoleh sebelumnya, dan mengaitkan pertanyaan-pertanyaan yang muncul sehingga timbul pengetahuan baru.

Dalam penelitian Fauzi (2011) menyatakan bahwa: "Guru dapat bertindak sebagai fasilitator yang memberikan arahan dan bimbingan dengan memberi pertanyaanpertanyaan menggiring (prompting questions) atau pertanyaan-pertanyaan menggali (probing questions) sehingga siswa menyadari akan kemampuan kognitif yang dimilikinya dan mengaitkan pengetahuan siswa dengan pengatahuan baru yang sedang dipelajarinya". Dengan melihat karakteristik dan kelebihan dari teknik probing dan prompting, jika dua teknik pembelajaran tersebut menggunakan pendekatan metakognisi penulis berharap dapat meningkatkan kemampuan penalaran matematis siswa.

Penelitian ini bertujuan untuk menelaah perbedaan antara teknik pembelajaran probing dan teknik pembelajaran prompting dalam peningkatan kemampuan penalaran matematis siswa.

\section{Metode Penelitian}

Penelitian ini dilaksanakan di SMP Negeri 35 dan SMPN 27 Medan. Penelitian ini merupakan penelitian eksperimen dengan jenis penelitiannya adalah quasi eksperiment. Dalam rancangan penelitian ini terdapat dua kelompok yang dipilih secara random (acak kelas, sebab kelas yang digunakan telah terbentuk sebelumnya), kemudian diberi pretest untuk mengetahui sejauh mana kesiapan siswa menerima pembelajaran kemudian diberi postes untuk melihat keadaan akhir setelah diberi perlakuan. Kelompok siswa pada kelas eksperimen 1 diberi perlakuan pembelajaran melalui pendekatan metakognisi berbantuan teknik probing (PMT-Probing), sedangkan kelas eksprimen 2 diberi perlakuan pembelajaran melalui pendekatan metakognisi berbantuan teknik prompting (PMT-Prompting).

Instrumen penelitian ini terdiri atas tes kemampuan awal, dan tes kemampuan penalaran matematis siswa berupa lembar proses jawaban siswa untuk dianalisis berdasarkan fase pengaturan diri dan level kogntif dan metakognitif siswa. Teknik analisis data yang digunakan dalam penelitian ini adalah analisis secara deskripstif dan inferensial.

\section{Hasil Penelitian dan Pembahasan}

\section{a. Deskripsi Kemampuan Penalaran Matematis}

Berdasarkan hasil pretes yang diberikan sebelum pembelajaran dan postes yang diberikan setelah pembelajaran kepada kedua kelas, dilakukan perhitungan untuk mengetahui besarnya peningkatan setelah pembelajaran. Peningkatan kemampuan penalaran matematis (N-Gain) siswa berdasarkan dua kelompok pembelajaran untuk setiap kategori KAM disajikan dalam bentuk diagram. 


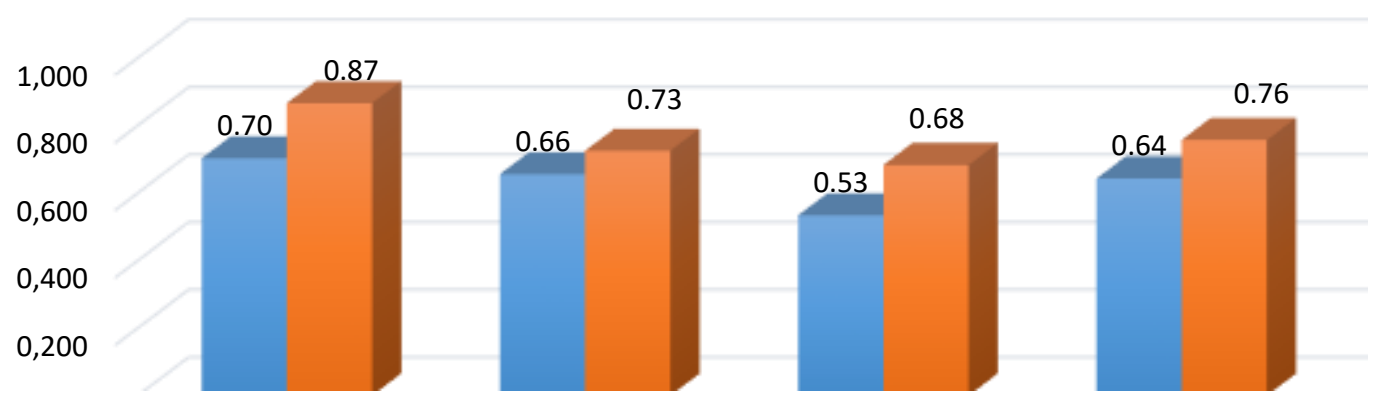

Gambar 1. Diagram Rerata N-Gain

Kemampuan Penalaran Matematika

Berikut disajikan dalam bentuk diagram peningkatan kemampuan penalaran matematika berdasarkan indikator:

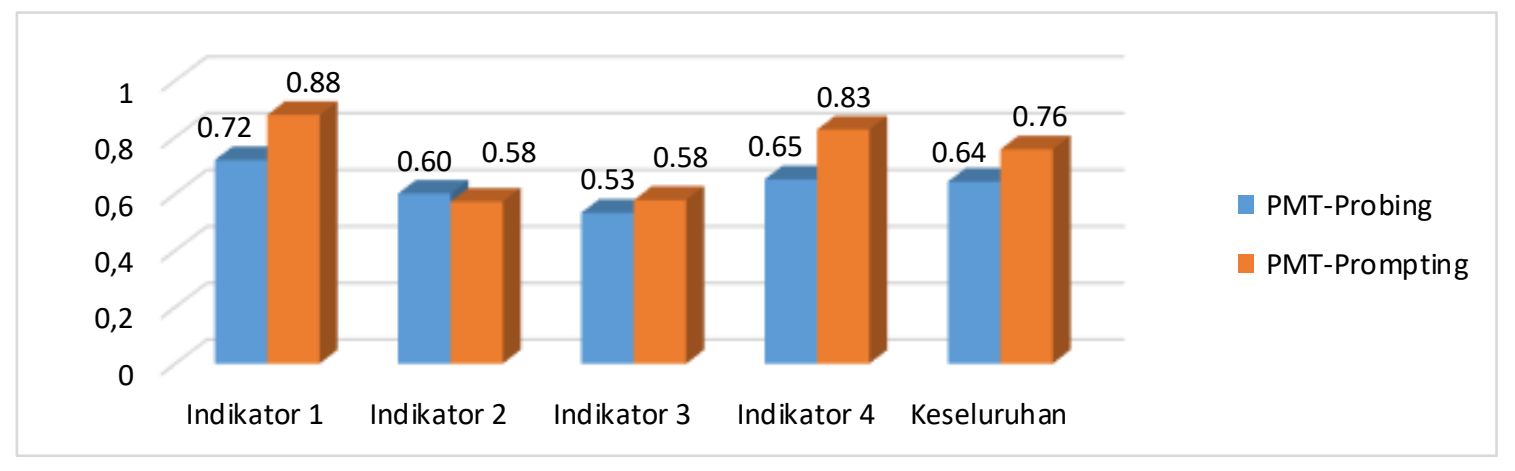

Gambar 2. Diagram Peningkatan

Kemampuan Penalaran Matematis

Keterangan:

Indikator $1:$ mengajukan dugaan

Indikator 2 : melakukan manipulasi

matematika

Indikator 3 : menarik kesimpulan dan memberikan alasan atau bukti

terhadap kebenaran solusi

Indikator 4 : menemukan pola atau sifat dari gejala matematis untuk membuat generalisasi

Analisis statistik yang digunakan untuk mengetahui terdapat atau tidak terdapatnya perbedaan peningkatan kemampuan penalaran matematis antara siswa yang diajar dengan PMT-Probing dan PMT-Prompting adalah ANAVA dua jalur dengan hasil nilai $F$ pada pendekatan pembelajaran (PMT-Probing dan PMTPrompting) sebesar 12,958 dengan nilai signifikansi 0,001 yang lebih kecil dari taraf signifikansi 0,05 yang berarti $\mathrm{H}_{0}$ ditolak. Dengan kata lain, terdapat perbedaan peningkatan kemampuan penalaran matematis antara siswa yang diajar melalui PMT-Probing dan siswa yang diajar melalui PMT-Prompting.

\section{b. Deskripsi Proses Jawaban Siswa pada Tes Kemampuan Penalaran \\ Proses Jawaban Matematika Siswa}

Proses jawaban matematika terkait kemampuan penalaran matematis siswa melalui PMT-Probing lebih rapi serta lebih lengkap daripada siswa yang diajar PMTPrompting. Kemampuan penalaran matematis yang dimaksud dalam penelitian ini adalah ungkapan gagasan atau ide-ide dalam menyelesaikan masalah matematika yang diberikan siswa dengan memperlihatkan aspek-aspek penalaran meliputi mengajukan dugaan, melakukan 
manipulasi matematika, menarik kesimpulan dan memberikan alasan atau bukti terhadap kebenaran solusi, dan menemukan pola atau sifat dari gejala matematis untuk membuat generalisasi. Berdasarkan hasil penelitian menunjukkan bahwa secara umum kemampuan penalaran matematis yang dimiliki siswa masih jauh dari yang diharapkan. Hal ini dapat dilihat dari persentase skor yang diperoleh siswa sesuai indikator kemampuan penalaran matematis pada masing-masing pembelajaran yang diberikan yaitu pembelajaran melalui PMTProbing dan pembelajaran melalui PMTPrompting yang menunjukkan bahwa kemampuan penalaran matematis siswa mengalami perbedaan pada setiap aspek. Dengan kata lain proses jawaban matematika siswa yang diajar melalui pendekatan PMT-
Prompting lebih baik daripada siswa yang diajar melalui PMT-Probing. Untuk rata-rata $N$-Gain kemampuan penalaran siswa yang diajar melalui PMT-Prompting $(=0,757)$ lebih tinggi daripada rata-rata $\mathrm{N}$-Gain kemampuan penalaran matematis siswa pada pembelajaran melalui PMT-Probing $(=0,643)$.

\section{Butir Soal Nomor 1}

Butir soal nomor 1 mengukur aspek mengajukan dugaan. Banyaknya siswa di kelas PMT-Probing dan PMT-Prompting yang memperoleh kategori baik dengan jawaban sempurna dengan mengemukakan dugaan yang tepat dan lengkap masingmasing adalah 18 siswa dan 25 siswa. Berikut ragam proses jawaban siswa pada aspek mengajukan dugaan dari kelas PMT-Probing dan PMT-Prompting.

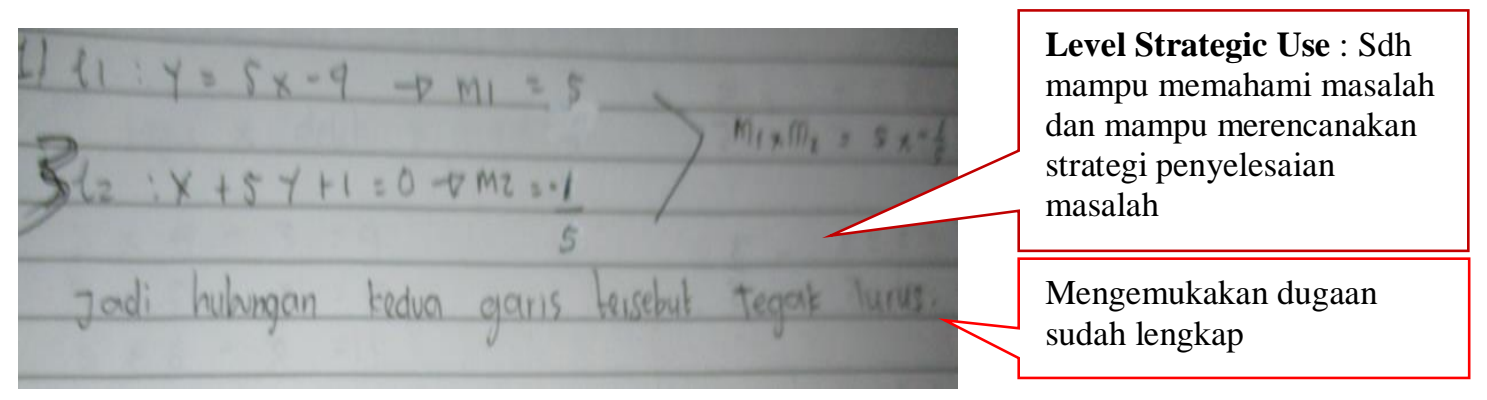

Gambar 3. Contoh proses jawaban siswa butir soal 1, kategori baik aspek mengajukan dugaan di kelas PMT-Probing

Analisis fase pemikiran tahap awal, siswa sudah menentukan tujuan dan merencanakan strategi dan tindakan menyusun strategi pelaksanaan berdasarkan informasi yang telah ia miliki sebagai persiapan untuk pelaksanaan keputusan dengan melibatkan pengalaman yang telah didapatkannya untuk membantu menyelesaikan masalahnya. Tentunya siswa menyadari kesulitan yang mungkin di alami selama melaksanakan strategi penyelesaiannya.

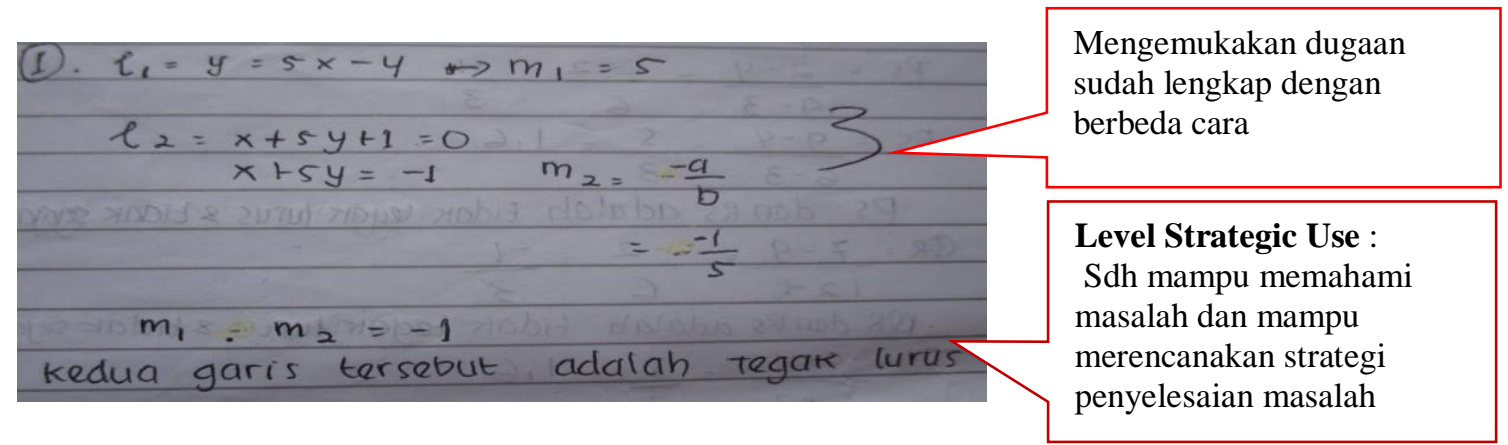

Gambar 4. Contoh proses jawaban siswa butir soal 1, kategori baik aspek mengajukan dugaan di kelas PMT-Prompting 
Berikut ragam proses jawaban siswa pada aspek mengajukan dugaan yang memperoleh kategori cukup pada kelas PMT-Probing dan PMT-Prompting.

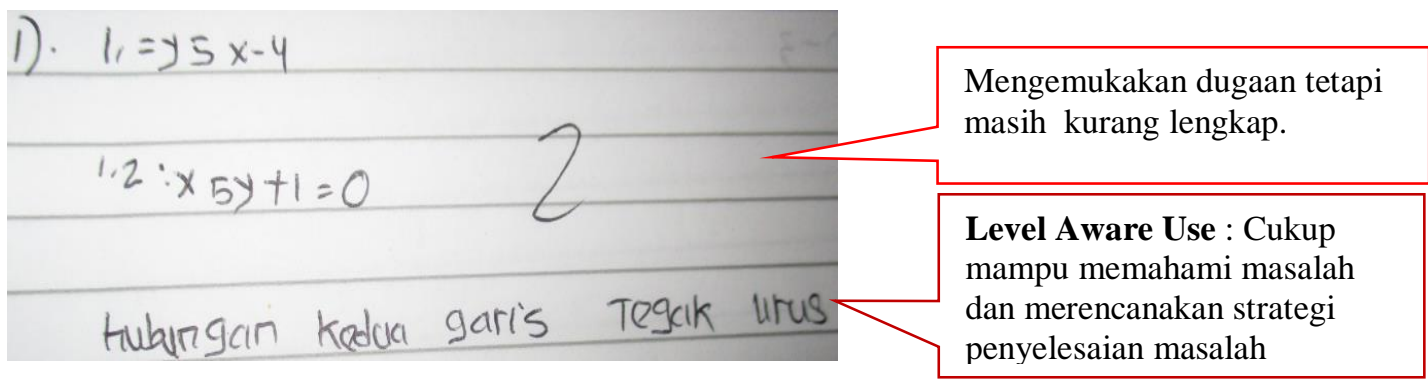

Gambar 5. Contoh proses jawaban siswa butir soal 1, kategori cukup aspek mengajukan dugaan di kelas

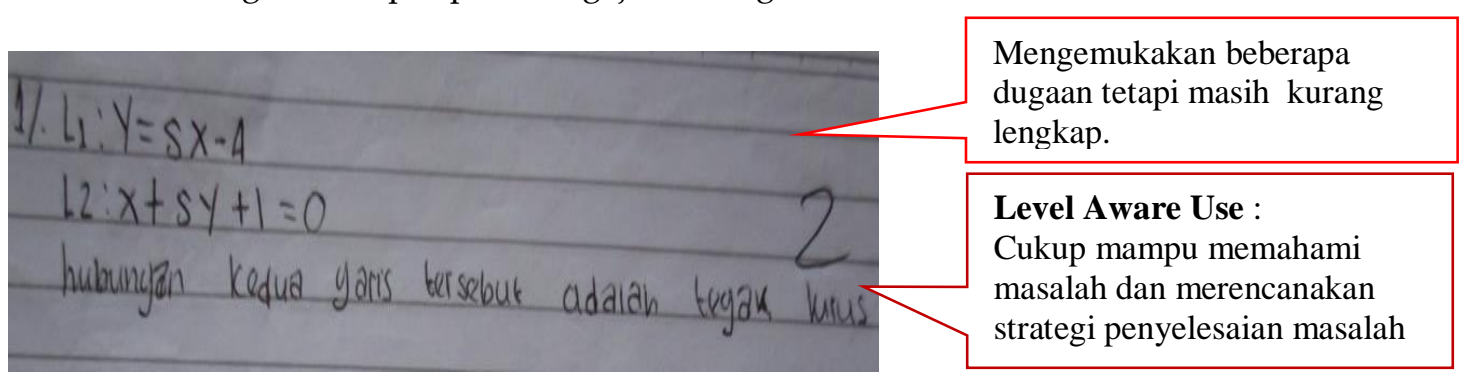

Gambar 6. Contoh proses jawaban siswa butir soal 1,

kategori cukup aspek mengajukan dugaan di kelas PMT-Prompting

Berikut ragam proses jawaban siswa pada aspek mengajukan dugaan yang memperoleh kategori kurang baik pada kelas PMT-Probing dan eksperimen 2.

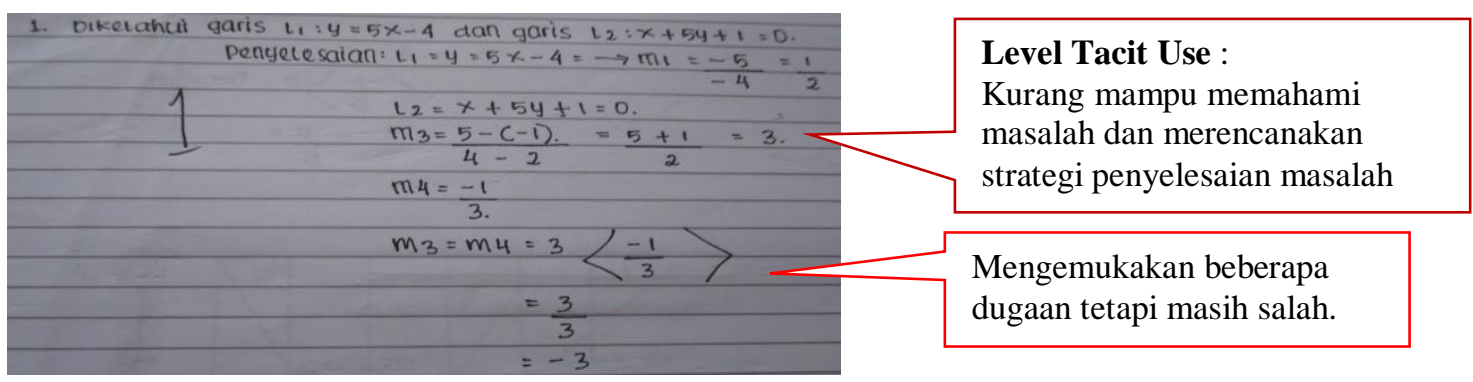

Gambar 7. Contoh proses jawaban siswa butir soal 1,

kategori kurang baik mengajukan dugaan di kelas PMT-Probing

\section{Simpulan dan Saran}

Berdasarkan hasil analisis dan temuan peneliti diperoleh beberapa kesimpulan yaitu (1) Terdapat perbedaan peningkatan kemampuan penalaran matematis siswa antara yang diajar dengan pendekatan metakognisi berbantuan teknik probing dan pendekatan metakognisi berbantuan teknik prompting. (2) Pembiasan strategi metakognisi berpengaruh pada fase pengaturan diri siswa, pada fase pemikiran awal dan pada fase kontrol kinerja, siswa sudah dapat menentukan tujuan dan merencanakan strategi dan tindakan menyusun strategi pelaksanaan berdasarkan 
informasi yang telah ia miliki sebagai persiapan untuk pelaksanaan keputusan dengan melibatkan pengalaman yang telah didapatkannya. Fase refleksi diri, siswa sudah menyadari kesulitan yang mungkin di alami selama melaksanakan strategi penyelesaiannya. (3) Proses metakognisi terjadi ketika subjek menyadari apa yang harus dilakukannya untuk memecahkan masalah, subjek membuat strategi penyelesaian pemecahan masalah, subjek menilai langkah dan hasil pengerjaan dan subjek meyakini jawabannya benar atau salah Siswa yang berada ditingkat level rendah dapat tergolong pada tingkat metakognisi Aware Use. Siswa dengan tingkat metakognisi Aware Use mempunyai aktivitas-aktivitas proses jawaban seperti siswa cukup mampu memahami masalah dengan baik, siswa cukup mampu merencanakan strategi penyelesaian masalah dengan baik, siswa cukup mampu menyadari konsep dan cara hitung yang digunakan dengan baik dan siswa cukup mampu melakukan evaluasi dengan baik. Siswa yang berada ditingkat level sedang tergolong pada tingkat metakognisi Strategic Use. Siswa dengan tingkat metakognisi Strategic Use mempunyai aktivitas-aktivitas proses jawaban seperti siswa mampu memahami masalah dengan baik, siswa mampu merencanakan strategi penyelesaian masalah dengan baik, siswa cukup mampu menyadari konsep dan cara hitung yang digunakan dengan baik dan siswa cukup mampu melakukan evaluasi dengan baik. Siswa dengan tingkat metakognisi Reflective Use mempunyai aktivitas-aktivitas proses jawaban seperti siswa mampu memahami masalah dengan baik, siswa mampu merencanakan strategi penyelesaian masalah dengan baik, siswa mampu menyadari konsep dan cara hitung yang digunakan dengan baik dan siswa mampu melakukan evaluasi dengan baik.

Berdasarkan penelitian yang telah dilakukan, peneliti mengemukakan beberapa saran untuk perkembangan penelitian selanjutnya, di antaranya:
Sebaiknya dilakukan wawancara untuk mengetahui proses metakognisi yang terjadi pada subjek, diusahakan situasi dan kondisi yang mendukung, agar bisa mendapatkan informasi yang lengkap. Untuk para guru, sebelum pembelajaran sebaiknya mengetahui teori tentang tipe-tipe berpikir siswa agar dapat diketahui lebih awal level berpikir siswa serta mempermudah dalam penelitian yang akan dilakukan.

\section{Daftar Pustaka}

Djaali. 2014. Psikologi Pendidikan. Jakarta: Bumi Aksara.

Fauzi. A. 2011. Peningkatan kemampuan koneksi matematis dan kemandirian belajar siswa dengan pendekatan pembelajaran metakognitif di sekolah menengah pertama. Bandung: PPS UPI.

Fauzi, A, Lestari, Arnah. 2016. Pengembangan Pembelajaran Matematika Dengan Pendekatan Metakognitif Untuk Meningkatkan Kemampuan Berpikir Logis dan Sikap Positif Siswa SMP. Laporan Hibah Bersaing Tahun I. Unimed. Medan

Hamdani, Nadran S dan Fauzi, Amin. 2017. The Difference between Mathematical Reasoning Ability Improvement by Learning with Meta Cognitive ApproachbAided Probing and Prompting Techniques in SMP Negeri 4 Sei Suka. World Journal of Educational Research, Volume 4 Nomor 1 Maret 2017

Safitri, dkk., (2015), Analisis Pemecahan Masalah Matematika Menggunakan Metakognisi, Jurnal Edumatika, UIN Semarang, Semarang.

Suyatno (2009). Menjelajah Pembelajaran Inovatif. Sidoarjo: Masmedia Buana Pustaka.

Walle, J.A. 2008. Pengembangan Pengajaran Matematika Sekolah Dasar dan Menengah Edisi Keenam Jilid 2. Jakarta: Erlangga.

Yamin, M., (2013). Strategi dan Metode dalam Model Pembelajaran, Penerbit Referensi (GP Press Group), Jakarta. 
Pelevelan Kemampuan Penalaran Matematis dengan Pembiasaan Strategi Metakognisi Siswa SMP

Yilmaz, I. 2010. Effects of Most to Least Prompting on Teaching Simple Progression Swimming Skill for Children with Autism. Education and Training in Autism and Developmental Disabilities, 45(3), 440-448:2010.

Zimmerman, Barry J. 2002, "Becoming a SelfRegulated Learner: An Overview". Theory Into Practice, Volume 41, Number 2, Spring 2002. 